U.S. DEPARTMENT OF THE INTERIOR

U.S. GEOLOGICAL SURVEY

\title{
GRAVITY AND MAGNETIC INVESTIGATIONS OF THE GHOST DANCE AND SOLITARIO CANYON FAULTS, YUCCA MOUNTAIN, NEVADA
}

By

D.A. Ponce and V.E. Langenheim

1995

\section{FCEIVED \\ MAY 261998 \\ OSTI}

Open-File Report 95-521

Prepared in cooperation with the

Nevada Operations Office

U.S. Department of Energy

(Interagency Agreement DE-A108-92NV10871)

This report is preliminary and bas not been reviewed for conformity with U.S. Geological Survey editorial standards or with the North American Stratigraphic Code. Any uee of trade, firm, or product names is for descriptive purposes only and does not imply endorsement by the U.S. Government.

Menlo Park, California

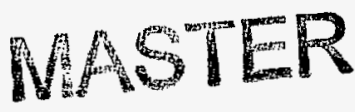

1995 


\section{DISCLAIMER}

This report was prepared as an account of work sponsored by an agency of the United States Government. Neither the United States Government nor any agency thereof, nor any of their employees, makes any warranty, express or implied, or assumes any legal liability or responsibility for the accuracy, completeness, or usefulness of any information, apparatus, product, or process disclosed, or represents that its use would not infringe privately owned rights. Reference herein to any specific commercial product, process, or service by trade name, trademark, manufacturer, or otherwise does not necessarily constitute or imply its endorsement, recommendation, or favoring by the United States Government or any agency thereof. The views and opinions of authors expressed herein do not necessarily state or reflect those of the United States Government or any agency thereof. 
U.S. DEPARTMENT OF THE INTERIOR

U.S. GEOLOGICAL SURVEY

GRAVITY AND MAGNETIC INVESTIGATIONS OF THE GHOST DANCE AND SOLITARIO CANYON FAULTS, YUCCA MOUNTAIN, NEVADA

By

D.A. Ponce and V.E. Langenheim ${ }^{1}$

GEOLOGICAL SURVEY OPEN-FILE REPORT 95-521

1 U.S. Geological Survey, Menlo Park, CA 


\section{CONTENTS}

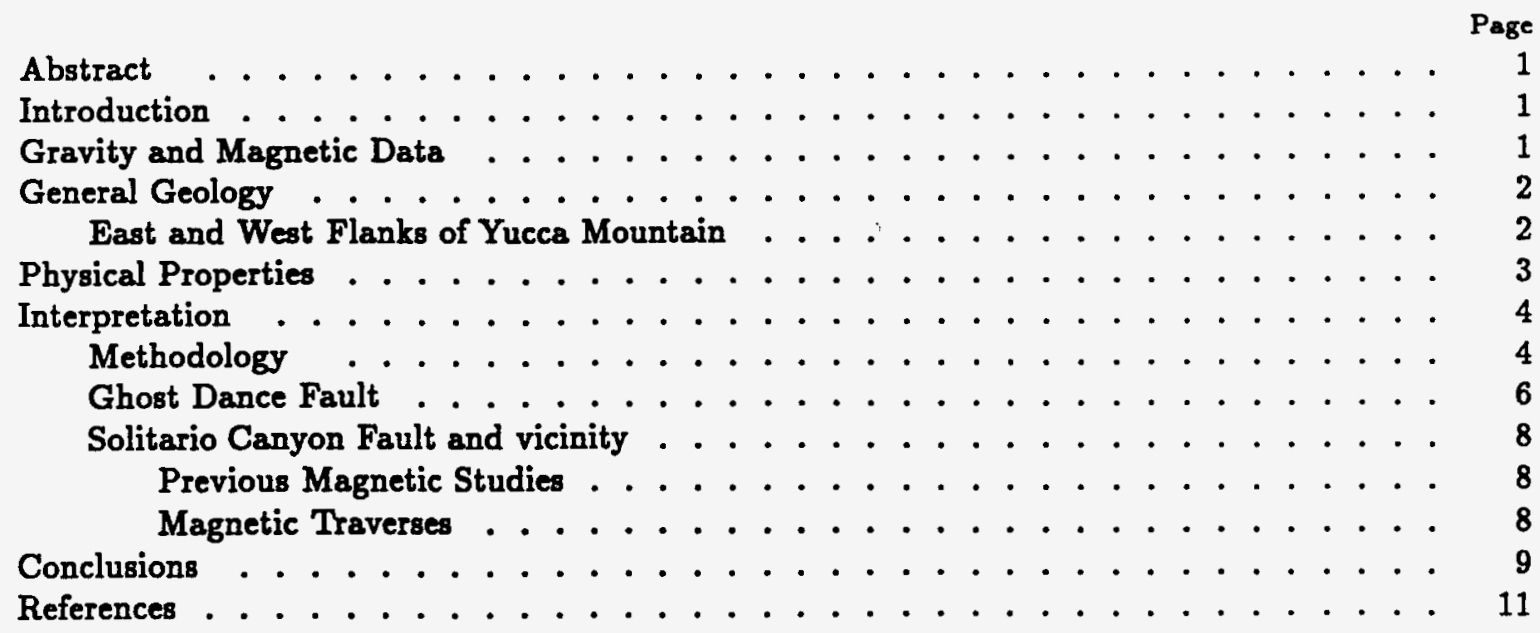

\section{TABLES}

TABLE 1. Geologic names and symbols . . . . . . . . . . . . . . . 14

2. Physical properties of rock units used in the models . . . . . . . . . . . 15

3. Physical properties of rock units used in the theoretical fault model . . . . . . 15

\section{ILLUSTRATIONS}

FIGURE 1. Generalized geologic map of study area ................ 16

2. Theoretical magnetic fault model . . . . . . . . . . . . . . 17

3a. Magnetic profile of Highway Ridge . . . . . . . . . . . . . . . . 18

3b. Gravity and magnetic profile of WT-2 wash . . . . . . . . . . . . . . . 19

3c. Magnetic profile of traverse J82 . . . . . . . . . . . . . . . . . . 20

3d. Gravity and magnetic profile of Antler Ridge . . . . . . . . . . . . . . 21

3e. Gravity and magnetic profile of Live Yucca Ridge . . . . . . . . . . . . 22

4. Gravity and magnetic model of Antler Ridge . . . . . . . . . . . . . . 23

5. Magnetic profiles across Solitario Canyon fault . . . . . . . . . . . . 24

6. Magnetic models across Solitario Canyon fault . . . . . . . . . . . . . 26 
Ground magnetic and gravity data collected along traverses across the Ghost Dance and Solitario Canyon faults on the eastern and western flanks, respectively, of Yucca Mountain in southwest Nevada are interpreted. These data were collected as part of an effort to evaluate faulting in the vicinity of a potential nuclear waste repository at Yucca Mountain. Gravity and magnetic data and models along traverses across the Ghost Dance and Solitario Canyon faults show prominent anomalies assocated with known faults and reveal a number of possible concealed faults beneath the eastern flank of Yucca Mountain. The central part of the eastern flank of Yucca Mountain is characterized by several small-amplitude anomalies that probably reflect small-scale faulting.

\section{INTRODUCTION}

Gravity and magnetic investigations of the Ghost Dance and Solitario Canyon faults were begun as part of an effort to help characterize faulting near a potential nuclear waste repository at Yucca Mountain. The study area is in the southwest quadrant of the Nevada Test Site (NTS) and is bounded by Crater Flat to the west, Yucca Wash to the north, Jackass Flats to the east, and Amargosa Valley to the south (fig. 1).

\section{GRAVITY AND MAGNETIC DATA}

Detailed gravity and magnetic data were collected along several profiles across the Ghost Dance fault, and detailed ground magnetic data were collected across the Solitario Canyon fault (fig. 1). Gravity data were reduced using the Geodetic Reference System of 1967 (International Union of Geodesy and Geophysics, 1971) and referenced to the International Gravity Standardization Net 1971 gravity datum (Morelli, 1974, p. 18). Gravity data were reduced to complete Bouguer anomalies for reduction densities of 2.67 and $2.00 \mathrm{~g} / \mathrm{cm}^{3}$ and include earth-tide, instrument drift, free-air, Bouguer, latitude, earth-curvature, and terrain corrections.

Ground magnetic data were collected with the sensor at $2.4 \mathrm{~m}$ above the surface along the profiles across the Ghost Dance and Solitario Canyon faults (fig. 1). Maximum station spacing was 20 paces or about $18 \mathrm{~m}$ while minimum spacing was 1 pace or about $1 \mathrm{~m}$. Locations of magnetic stations between surveyed gravity stations were determined by interpolation using the number of paces and the surveyed distances between the gravity stations. 


\section{GENERAL GEOLOGY}

The geologic units that underlie the study area consist of Precambrian and Paleozoic rocks, a series of Miocene ash-flow tuffs interbedded with relatively thin ash-fall and reworked tuffs, and late Tertiary and $Q$ uaternary surficial deposits. Pre-Cenozoic sedimentary and metamorphic rocks in the study area are predominantly limestone and dolomite, with lesser amounts of argillite, quartzite, and marble (U.S. Geological Survey, 1984). The Paleozoic Devils Gate Limestone, Simonson Dolomite, and Eleana Formation are exposed in the northeastern part of the study area at Calico Hills (McKay and Williams, 1964; Frizzell and Shulters, 1990). The Lone Mountain Dolomite and the Roberts Mountain Formation were penetrated in drill-hole UE-25p\#1 (Carr and others, 1986) west of Fran Ridge (fig. 1, P\#1), at depths of 1,244 and 1,667 m, respectively (Muller and Kibler, 1984).

The stratigraphic names of the Cenozoic volcanic rock units which occur at Yucca Mountain have undergone revision (Sawyer and others, 1994), elevating formation names to group and members to formations. In order to be consistent with this work the revisions will be used throughout this report (table 1). In ascending order the Cenozoic volcanic units are: (1) older ash-flow tuffs, (2) Lithic Ridge Tuff, (3) Crater Flat Group, (4) Calico Hills Formation, (5) Paintbrush Group, and (6) Timber Mountain Group. The Crater Flat Group is composed of the Tram, Bullfrog, and Prow Pass Tuffs, the Paintbrush Group is composed of the Topopah Spring, Pah Canyon, Yucca Mountain, and Tiva Canyon Tuffs, and the Timber Mountain Group is composed of the Rainier Mesa and Ammonia Tanks Tuffs. The Volcanics of Fortymile Wash, which are younger than the tuff sequence exposed at Yucca Mountain, occur northeast of Yucca Wash.

\section{EAST AND WEST FLANKS OF YUCCA MOUNTAIN}

A number of prominent north-trending, down-to-the-west, and normal faults characterize Yucca Mountain and vicinity. These block-bounding faults define a series of east-tilted, 1 - to 4-km-wide structural blocks that include brecciated zones along the faults up to about 500 $m$ wide. The Ghost Dance fault, which has been identified within the potential repository area, has been mapped as a north-trending down-to-the-west fault with an offset of about $30 \mathrm{~m}$ near the southern edge of the repository (Spengler and others, 1993, 1994).

Another prominent fault is the Solitario Canyon fault which lies near the western boundary of the repository block at Yucca Mountain. Several previous studies have investigated the rate and age of motion along this fault. A basaltic dike dated at $10 \mathrm{Ma}$ (Carr and Parrish, 1985) intrudes the northern trace of the fault. Exposures of the dike in Trench 10 indicate that the dike both intrudes the fault plane and has been subsequently offset by episodes of movement on the Solitario Canyon fault (Crowe and others, 1995). Using relative degree of tilting of the subhorizontal tuff layers, Scott (1990) calculated a rate of $0.19 \mathrm{~mm} / \mathrm{yr}$ of 
dip-slip movement along the Solitario Canyon fault between 13 and $11.5 \mathrm{Ma}$ and a rate of $0.01 \mathrm{~mm} / \mathrm{yr}$ between $11 \mathrm{Ma}$ and the present. Carr (1984; p. 92) has claimed that less than $2 \mathrm{~m}$ of offset has occurred along the Solitario Canyon fault since $10 \mathrm{Ma}$. More recent studies of the Solitario Canyon fault (A.R. Ramelli, written commun., 1995) support Scott's (1990) earlier results of variable rates of movement along the fault, with only small amounts of middle to late Quaternary movement.

\section{PHYSICAL PROPERTIES}

Rock density information is available from rock sampling, core sampling, density profiling and geophysical logs. Mean densities of more than 400 rock samples from the NTS were summarized by Ponce (1981), geophysical logs of 40 drill holes were summarized by Nelson and others (1991), and magnetic properites of various volcanic rocks were described by Bath (1968), Bath and Jahren (1984), and Rosenbaum and Snyder (1985). A summary of the physical properties used in the gravity and magnetic models is shown in table 2.

The density data described above indicate that there are significant density contrasts between alluvium, zeolitized tuffs, partly welded tuffs, and welded tuffs that range from about $0.2 \mathrm{~g} / \mathrm{cm}^{3}$ between zeolitized, partly welded tuffs and welded tuffs and up to about 0.6 $\mathrm{g} / \mathrm{cm}^{3}$ between unwelded and welded tuffs. An average density contrast of about 0.2 to 0.3 $\mathrm{g} / \mathrm{cm}^{3}$ works well for estimating vertical offsets along faults in Midway Valley (Ponce, 1993).

Previous studies have shown that remanent magnetization is responsible for causing most of the magnetic anomalies present within the Nevada Test Site and vicinity (Bath, 1968; Bath and Jahren, 1984). In particular many of the north-trending, linear magnetic anomalies are caused by vertical offset of the moderately to highly magnetic Topopah Spring Tuff (Bath and Jahren, 1984). In general, magnetic highs occur over the upthrown block. The averaged values listed in table 2 do not take into account the widely varying magnetization of some units. 


\section{INTERPRETATION}

\section{METHODOLOGY}

Because detailed interpretations of geophysical data can be somewhat subjective, an account of the methodology used to infer faulting and the inherent limitations of geophysical modeling is presented. Observed detailed gravity and magnetic profiles were compared to geologic and structural information, primarily displayed on the geologic map of Yucca Mountain by Scott and Bonk (1984). This comparison yields information on the gravity and magnetic signature of known faults, fractures, structures, and of the various volcanic formations at Yucca Mountain. The gravity and magnetic signatures of known features combined with theoretical signatures or modeling can then be used to infer unknown or concealed features.

In general, the gravity effect of a fault appears as a low over the downthrown block and a high over the upthrown block. The amplitude of the anomaly is related to the amount of offset and depth of the feature, while the asymmetry of the anomaly is related to the dip of the fault plane. Other features associated with faulting may dominate the gravity signature; for example, a gravity low may be associated with a fault zone, due to brecciation and the subsequent decrease in density. The ability of gravity data to resolve a feature is directly related to the density contrast, depth, geometry, and how well the feature is isolated from other nearby features.

The magnetic effect of a fault is much more complex, due to the inherent directional nature of rock magnetism and the fact that total magnetization is composed of an induced effect and a remanent effect. The induced magnetization is in the direction of the Earth's magnetic field, whereas the remanent magnetization can be in a completely different direction. The magnetic effect of a down-to-the-west vertical fault with infinite offset was illustrated by Bath and Jahren (1984) by modeling the four main anomaly-producing units that occur at Yucca Mountain (fig. 2). Although Bath and Jahren (1984) modeled the effect of these units for both east-west and north-south striking faults, for the purposes of this report, only the case for north-south striking faults is shown. The four units in the model are the Tiva Canyon Tuff, Topopah Spring Tuff, Bullfrog Tuff, and Tram Tuff, and their physical properties are described in table 3 . The model is based on the magnetic properties and thickness of the tuff units penetrated in drill-hole USW-G1 (Spengler and others, 1981; Rosenbaum and Snyder, 1985) and are essentially the same as the averaged properties shown in table 2. The shape and amplitude of the anomalies are also applicable for down-to-the-east faults by simple rotation of $180^{\circ}$ about the zero point of the horizontal axis. An important result of this model is that the overriding or dominant magnetic signature of a normal fault at Yucca Mountain and vicinity is caused by the Topopah Spring Tuff. 
In summary, two geophysical fault models have been used to infer faulting on the eastern flank of Yucca Mountain: a down-to-the-west fault model and a fault zone model. The downto-the-west fault model is characterized by a gravity low on the west, a gravity high on the east, and a magnetic signature as shown in figure 2. Two mapped faults near the eastern end of Antler Ridge (fig. 3d) exemplify the geophysical signature of a down-to-the-west fault. The fault zone model is characterized by both a gravity and magnetic low, exemplified by the gravity and magnetic signature over the Ghost. Dance fault in figures $3 \mathrm{~b}$ and $3 \mathrm{~d}$. Although the authors recognize that other fault types may be present along the eastern flank of Yucca Mountain, such as down-to-the east faults, these faults have not been shown because most geophysical and geologic data indicate that most faults are down-to-the-west.

As an aid to the reader, three levels of confidence for interpretation of possible faulting are indicated by bold, medium, and fine width lines that denote high, medium, and low confidence levels, respectively (see figs $3 \mathrm{a}-\mathrm{e}$ ). High confidence faults are those that correlate to a gravity anomaly, magnetic anomaly, and a mapped fault. Medium confidence faults are those that correlate to two of the following features: gravity anomaly, magnetic anomaly, or a mapped fault. Finally, low confidence faults are those that correlate to only one of the following features: gravity anomaly, magnetic anomaly, or a mapped fault. In addition, the confidence of a possible fault may be increased if the geophysical signature is prominent.

Although geophysical modeling can also be used to delineate small-scale features, the required detailed density and magnetic property information is not available to resolve such small-scale features along these detailed traverses. Thus, only the gross features are contained in the models presented here. Because of the overriding magnetic effect of the Topopah Spring Tuff, inferred faults or structure below the Topopah Spring Tuff may not be very well constrained in the magnetic models. The models represent one set of possible geometries that account for the observed gravity and ground magnetic anomalies. The models are not unique solutions but are based on geologic mapping, geologic cross sections, stratigraphic thickness, and physical property measurements. The two-dimensional models may not adequately account for the three-dimensionality of the underlying structure, and abrupt changes in magnetic properties of a given rock unit may make some models poorly constrained. 


\section{GHOST DANCE FAULT}

Several gravity or magnetic profiles have been collected across the Ghost Dance fault by the U.S. Geological Survey. These profiles are described from south to north and are located along Highway Ridge; WT-2 Wash; J82, a profile that cuts obliquely across several ridges and washes; Antler Ridge; and Live Yucca Ridge (fig. 1).

An 800-m long magnetic profile along Highway Ridge (HR, fig. 1; fig. 3a) reveals the Ghost Dance fault with an anomaly amplitude of about 100 nanoteslas ( $\mathrm{n}$ ). In addition, magnetic data reveal the presence of other possible small-scale faults, most of which correlate to mapped faults shown at a scale of $1: 12,000$ by Scott and Bonk (1984).

A gravity and magnetic profile along WT-2 Wash was previously described by Oliver and Sikora (1994) and is shown here for comparison (fig. 3b). Their preliminary results show an 0.1 to 0.2 milligal ( $\mathrm{mGal}$ ) gravity low over a $200-\mathrm{m}$ wide zone that includes the mapped location of the Ghost Dance fault. This decrease in gravity may mark a zone of brecciation. Two other faults east of the Ghost Dance fault at distances of 900 and $1000 \mathrm{~m}$ (SF, fig. 3b) were also detected by seismic reflection data of Daley and others (1994). Ground magnetic data reveal a 400-n T low about $110-\mathrm{m}$ wide that is centered about $30 \mathrm{~m}$ east of the Ghost Dance fault. Oliver and Sikora (1994) suggested that the magnetic low probably marks a zone of brecciation within the normally polarized Topopah Spring Tuff. In addition to the interpretations discussed by Oliver and Sikora (1994), magnetic data indicate the presence of other possible small-scale faulting (fig. $3 \mathrm{~b}$ ), most of which correlate to mapped faults by Scott and Bonk (1984).

Another previously described magnetic traverse across the Ghost Dance fault was collected by Bath and Jahren (1984). These data were digitized from that publication and displayed here for comparison (fig. 3c). Although the location of the profile was not accurately displayed on Bath and Jahren's (1984) index map, the profile extends southeast from approximately Yucca Mountain Crest and obliquely crosses several ridges and washes on the east flank of Yucca Mountain (J82, fig. 1). These data reveal a 400-nT magnetic low about 150-m wide similar to the magnetic signature of the Ghost Dance fault observed on traverse WT-2 (fig. 3b). A number of other anomalies present along this profile may be related to small-scale faulting. However, because of the poorly described location of the profile and possible magnetic terrain effects that may exist along the profile, it is difficult to correlate these anomalies to mapped faults or to infer the cause of some the anomalies.

To obtain a better understanding of the gravity and magnetic signature of the Ghost Dance fault, recent traverses were located along two of the east-trending ridges along the east flank of Yucca Mountain (AR and LYR, fig.1). Although interpretation of magnetic data along traverse WT-2 and J82, that are located or partly located in washes, is complicated by magnetic effects of rocks above the magnetic field sensor, magnetic data collected along ridge tops is complicated by massive outcrops and float exposed at the surface and directly 
below the sensor. Both of these effects complicate the interpretation process.

These two gravity and magnetic profiles across the entire east flank of Yucca Mountain (fig. 3d and 3e) are characterized by numerous small-amplitude gravity and magnetic anomalies probably associated with small-scale faulting. In addition, the profiles show lowamplitude anomalies associated with the Ghost Dance fault and the Sundance fault. These two profiles also contain greater background variation or noise than, for example, the WT-2 traverse (fig. $3 \mathrm{~b}$ ) because of massive rock outcrops of reversely magnetized tuff at the surface and directly below the magnetic field sensor.

Along Antler Ridge, gravity data (fig. 3d) reveal small-amplitude lows associated with the Ghost Dance and Sundance fault zones at distances of about 1050 and $1250 \mathrm{~m}$, respectively. The gravity lows associated with the Ghost Dance and Sundance faults have an amplitude of about $0.2 \mathrm{mGal}$ and suggest a zone of lower-density rocks about 100- and 50-m wide, respectively. The Ghost Dance fault is associated with about a $70-\mathrm{n} \mathrm{T}$ magnetic low with a width of about $80 \mathrm{~m}$. Two mapped faults near the eastern end of the profile at distances of 1900 and $2100 \mathrm{~m}$ exemplify the geophysical signature of a down-to-the-west fault and thus support the practicallity of the theoretical fault models. Together, gravity and magnetic data also indicate the presence of other anomalies that are probably associated with small-scale faulting, most of which correlate to mapped faults or fractures (Scott and Bonk, 1984).

Along Live Yucca Ridge, gravity data (fig. 3e) indicate the presence of about a 0.2-m Gal low about $100-\mathrm{m}$ wide associated with the Ghost Dance fault. In contrast, there is no gravity low associated with the Sundance fault along Live Yucca Ridge. Magnetic data along Live Yucca Ridge reveal an anomaly over the Ghost Dance fault similar in shape and amplitude to the Antler Ridge anomaly over the Ghost Dance fault. In addition, the magnetic anomaly over the Ghost Dance fault for these ridges is similar in shape to the anomaly over the Ghost Dance fault observed along washes along traverses WT-2 and J82, but only a quarter of the amplitude. This difference is partly related to magnetic terrain effects. Together, gravity and magnetic data may reveal the presence of other small-scale fracturing or faulting, most of which correlate to mapped fractures or faults (Scott and Bonk, 1984).

A gravity and magnetic model (fig. 4) along the Antler Ridge traverse (AR, fig. 1) supports geologic modeling and indicates that the Ghost Dance fault is a down-to-the-west normal fault with a dip of about $70^{\circ}$. Because of the overriding magnetic effect of the Topopah Spring Tuff, inferred faults or structure below the Topopah Spring Tuff may not be very well constrained in the model. The model also indicates that the average physical property measurements assigned to entire formations are sufficient to account for the larger anomalies observed along the Antler Ridge traverse. However, averaged properties may not be adequate to resolve in detail small-scale geologic features such as the Ghost Dance, Sundance, or other faults that juxtapose rocks with small density or magnetic property contrasts. 


\title{
SOLITARIO CANYON FAULT AND VICINITY
}

\author{
PREVIOUS MAGNETIC STUDIES
}

Bath and Jahren (1984) have shown that the primary source of north-trending anomalies in the Yucca Mountain area is caused by offsets of the normally polarized Topopah Spring Tuff. They suggested that a minimum vertical offset of $70 \mathrm{~m}$ is required to produce a significant aeromagnetic anomaly for a survey flown at $152 \mathrm{~m}$ above the ground surface. Aeromagnetic profile F77 (fig. 1) by Bath and Jahren (1984) across the Solitario Canyon fault, passing just south of drill-hole USW G-3, was interpreted in terms of vertical offsets of the Topopah Spring Tuff. They estimated an offset of almost $500 \mathrm{~m}$ along the Solitario Canyon fault for the Topopah Spring Tuff.

Bath and Jahren (1985) described a magnetic high (A, fig. 1) of $290 \mathrm{nT}$ detected on one north-south flightline flown over the west side of Yucca Mountain. An earlier aeromagnetic survey flown at the same height above terrain $(122 \mathrm{~m})$ and same flightline spacing $(400 \mathrm{~m})$ but along east-west flightlines did not detect this magnetic high. Bath and Jahren suggested that the anomaly is caused by a combination of three factors: (1) terrain effect, (2) proximity to the magnetic high caused by the upthrown block of the Solitario Canyon fault, and (3) increase in magnetization in the Topopah Spring Tuff. They also introduced the possibility that the anomaly is caused by a small intrusive body but stated that the data then available did not favor that interpretation.

\section{MAGNETIC TRAVERSES}

Five magnetic traverses across the Solitario Canyon fault (fig. 1) show a range of magnetic signatures. The northernmost traverse, SCF1, is located just $10 \mathrm{ft}$ south of Trench 10, where a basaltic dike intrudes the fault trace (fig. 5a). A magnetic low with an amplitude of about $100 \mathrm{nT}$ coincides with the location of the dike at a distance of about $40 \mathrm{~m}$. A magnetic model of the ground magnetic data indicates that a vertical, reversely-polarized dike $1.6 \mathrm{~m}$ wide can produce a magnetic low that matches the amplitude of the observed low (fig. 6a). Another low of about $100 \mathrm{nT}$ is located to the west, just beyond the western margin of the trench. Perhaps this low indicates another basaltic dike at this location or is the effect of a rubble pile near the western end of the traverse. Although SCF 1 is only $75-m$ long, it does not show the large variation expected for a fault with significant offset.

Two traverses located just south of SCF1 display very different magnetic signatures. A magnetic high of about $150 \mathrm{nT}$ coincides with the location of basaltic dike along traverse SCF2 (fig. 5b). The location of one strand of the Solitario Canyon fault is associated with the eastern edge of a magnetic high of $250 \mathrm{nT}$ along SCF3 (fig. 5c). These magnetic signatures are not typical of either a reversely magnetized basaltic dike or of a down-to- 
the-west displacement of the tuff sequence along a steeply dipping normal fault. Traverse SCF 3 is probably not long enough to image fully the fault anomaly, and both SCF2 and SCF3 may suffer effects of magnetic sources above the sensor as both are located within the northern reaches of Solitario Canyon. Profile SCF1 is located within a broad, gentle saddle and therefore should not be affected by magnetic sources above the sensor.

Traverses SCF4 and SCF5 (fig. 5d and 5e) are longer traverses that show a more typical magnetic signature of offset tuff sequences:along steeply dipping normal faults, with a magnetic high occurring over the upthrown block and a magnetic low occurring over the downthrown block (see fig. 14 and 16 of Bath and Jahren, 1984). The amplitude of the fault anomaly increases from about $320 \mathrm{nT}$ along SCF4 to over $650 \mathrm{nT}$ along SCF5. As. suming that the magnetization of the Topopah Spring Tuff is the same along both traverses, these data suggest that offset along the Solitario Canyon fault increases to the south. Both traverses show a bench on the west side of the associated magnetic anomaly. Modeling of SCF5 (fig. 6b) suggests an offset of $300 \mathrm{~m}$ along the eastern strand of the Solitario Canyon fault near its trenched location in SCF4 and an offset of 50-100 m along a fault within the Solitario Canyon wash. In order to fit the broad low over the downdropped block, it was necessary to reduce the modeled magnetization of the tuff units within the 75 -m wide block caught between the two fault strands. This loss of magnetization can be accomplished in two geologically plausible ways: (1) alteration of magnetite caused by fluids within the fault zone and (2) brecciation within the fault zone, causing the remanent magnetization to be effectively randomized and reduced in amplitude.

On the eastern part of the SCF5 traverse, a magnetic high of about $200 \mathrm{nT}$ may reflect a change in magnetization within the Topopah Spring Tuff sequence. A ground magnetic profile collected by Bath and Jahren (1985) farther south (C83 on fig. 1) also shows high-frequency anomalies that may be caused by changes in magnetization within the Topopah Spring Tuff. Fault offsets within the Topopah Spring Tuff may also cause these high-frequency anomalies. A careful study of the magnetic properties of the Topopah Spring Tuff within a stratigraphic context could help constrain the source of these anomalies. Independent data, such as detailed gravity data along the ground magnetic profiles, could also help resolve whether the high-frequency magnetic anomalies are caused by faults.

\section{CONCLUSIONS}

Gravity and magnetic data and models along traverses across the Ghost Dance and Solitario Canyon faults show prominent anomalies assocated with known faults and reveal a number of possible concealed faults beneath the eastern flank of Yucca Mountain. The central part of the eastern flank of Yucca Mountain is characterized by several small-amplitude anomalies that probably reflect small-scale faulting.

These gravity and magnetic studies show that they are useful for delineating major faults 
at Yucca Mountain such as the Ghost Dance and Solitario Canyon faults, and minor faults such as those along the eastern flank of Yucca Mountain. Additional detailed gravity and magnetic data could provide an effective means to better define the location of known or suspected faults and to locate concealed or unknown faults. 


\section{REFERENCES}

Bath, G.D., 1968, Aeromagnetic anomalies related to remanent magnetism in volcanic rock, Nevada Test Site, in Eckel, E.B., ed., Nevada Test Site: Geological Society of America Memoir 110, p. 135-146.

Bath, G.D., and Jahren, C.E., 1984, Interpretations of magnetic anomalies at a potential repository site located in the Yucca Mountain area, Nevada Test Site: U.S. Geological Survey Open-File Report 84-120, 40 p. (NNA.870323.0194)

Bath, G.D., and Jahren, C.E., 1985, Investigation of an aeromagnetic anomaly on the west side of Yucca Mountain, Nye county, Nevada: U.S. Geological Survey Open-File Report $85-459,24$ p.

Carr, W.J., 1984, Regional structural setting of Yucca Mountain, southwestern Nevada, and late Cenozoic rates of tectonic activity in part of the southwestern Great Basin, Nevada and California: U.S. Geological Survey Open-File Report 84-854, 109 p.

Carr, W.J, and Parrish, L.D., 1985, Geology of drill hole USW VH-2, and structure of Crater Falt, southwestern Nevada: U.S. Geological Survey Open-File Report 85-475, 41 p.

Carr, M.D., Waddell, S.J., Vick, G.S., Stock, J.M., Monsen, S.A., Harris, A.G., Cork, B.W., and Byers, F.M., 1986, Geology of drill hole UE25p\#1: A test hole into pre-Tertiary rocks near Yucca Mountain, southern Nevada: U.S. Geological Survey Open-File Report 86-175, 87 p.

Crowe, B., Perry, F., Geissman, J., McFadden, L., Wells, S., Murrell, M., Poths, J., Valentine, G.A., Bowker, L., and Finnegan, K., 1995, Status of volcanism studies for the Yucca Mountain Site characterization project: Los Alamos National Laboratory Report LA-12908-MS, p. 2-11.

Daley, T.M., Majer, E.L., and Karageorgi, Eleni, 1994, Combined analysis of surface reflection imaging and vertical seismic profiling at Yucca Mountain, Nevada: Lawrence Berkeley Laboratory Report LBL-36467, 44 p.

Frizzell, V.A., and Shulters, Jacqueline, 1990, Geologic map of the Nevada Test Site, southern Nevada: U.S. Geological Survey Miscellaneous Investigations Series Map I-2046, scale $1: 100,000$.

International Union of Geodesy and Geophysics, 1971, Geodetic Reference System 1967: International Association of Geodesy Special Publication no. 3, 116 p. (NNA.901127.0202)

McKay, E.J., and Williams, W.P., 1964, Geology of the Jackass Flats quadrangle, Nye County, Nevada, U.S. Geological Survey Geologic Quadrangle Map GQ-368, scale 1:24,000. (HQS.880517.1339)

Morelli, C., ed., 1974, The International Gravity Standardization Net, 1971: International Association of Geodesy Special Publication no. 4, 194 p. (NNA.901127.0203) 
Muller, D.C., and Kibler, J.E., 1984, Preliminary analysis of geophysical logs from drill hole UE-25p\#1, Yucca Mountain, Nye County, Nevada, U.S. Geological Survey Open-File Report 84-649, 14 p. (SRX.850104.0241)

Nelson, P.H., Muller, D.C., Schimschal, Ulrich, and Kibler, J.E., 1991, Geophysical logs and core measurements from forty boreholes at Yucca Mountain, Nevada: U.S. Geological Survey Geophysical Investigations Map GP-1001, 64 p., 10 sheets, 1:1,200. (NNA.920211.0022)

Oliver, H.W., and Sikora, R.F., 1994, Gravity and magnetic data across the Ghost Dance fault in WT-2 Wash, Yucca Mountain, Nevada: U.S. Geological Survey Open-File Report 94-413-A, 22 p.

Ponce, D.A., 1981, Preliminary gravity investigations of the Wahmonie site, Nevada Test Site, Nye County, Nevada: U.S. Geological Survey Open-File Report 81-522, 64 p. (HQS.880517.2824)

Ponce, D.A. 1993, Geophysical investigations of concealed faults near Yucca Mountain, southwest Nevada: American Nuclear Society Proceedings of the Fourth Annual International Conference on High level Waste Management, v. 1, p. 168-174. (NNA.931025.0028)

Rosenbaum, J.G., and Snyder, R.B., 1985, Preliminary interpretation of paleomagnetic and magnetic property data from drill holes USW G-1, G-2, G-3, and VH-1 and surface localities in the vicinity of Yucca Mountain, Nye County, Nevada: U.S. Geological Survey Open-File Report 85-49, 73 p.

Sawyer, D.A., Fleck, R.J., Lanphere, M.A., Warren, R.G., Broxton, D.E., and Hudson, M.R., 1994, Episodic caldera volcanism in the Miocene southwestern Nevada volcanic field: ${ }^{40} \mathrm{Ar} /{ }^{39} \mathrm{Ar}$ geochronologic framework and revised stratigraphy: Geological Society of America Bulletin, v. 106, p. 1304-1318.

Scott, R.B., 1990, Tectonic setting of Yucca Mountain, southwest Nevada, in Wernicke, B.P., ed., Basin and Range extensional tectonics near the latitude of Las Vegas, Nevada: Geological Society of America Memoir 176, p 251-282.

Scott, R.B., and Bonk, Jerry, 1984, Preliminary geologic map of Yucca Mountain, Nye County, Nevada with geologic sections: U.S. Geological Survey Open-File Report 84494, scale 1:12,000. (HQS.880517.1443)

Spengler, R.W., Braun, C.A., Linden, R.M., Martin, L.G., Ross-Brown, D.M., and Blackburn, R.L., 1993, Structural Character of the Ghost Dance fault, Yucca Mountain, Nevada: American Nuclear Society Proceedings of the Fourth Annual International Conference on High level Waste Management, v. 1, p. 653-659.

Spengler, R.W., Braun, C.A., Martin, L.G., and Weisenberg, C.W., 1994, The Sundance fault: a newly recognized shear zone at Yucca Mountain, Nevada: U.S. Geological Survey Open-File Report 94-49, 11 p. (NNA.940128.0019)

Spengler, R.W., Byers, F.M., Jr., and Warner, J.B., 1981, Stratigraphy and structure of volcanic rocks in drill hole USW-G1, Yucca Mountain, Nye County, Nevada: U.S. Geological Survey Open-File Report 81-1349, 50 p. (NNA.870406.0222) 
U.S. Geological Survey, 1984, A summary of geologic studies through January 1, 1983, of a potential high-level radioactive waste repository site at Yucca Mountain, southern Nye-County, Nevada: U.S. Geological Survey Open-File Report 84-792, 103 p. (NNA.891009.0305)

NOTE: Parenthesized numbers following each cited reference are for U.S. Department of Energy Office of Civilian Radioactive Waste Management Records Management purposes only and should not be used when ordering the publication. 
TABLE 1.-Geologic names and symbols. Modified from Sawyer and others (1994)

\begin{tabular}{ll}
\hline \multicolumn{1}{c}{ Name of Unit } & Quaternary \\
\hline \multicolumn{1}{c}{ Miocene } & \\
\hline \multicolumn{1}{c}{ Alluvium and colluvium } & Q ac \\
\hline Volcanics of Fortymile Canyon & Thc \\
Timber Mountain Group & Twa \\
Ammonia Tanks Tuff & Tm \\
Rainier Mesa Tuff & Twx \\
tuff unit "X" & \\
Paintbrush Group & Thc \\
Tiva Canyon Tuff & Ty \\
Yucca Mountain Tuff & Typ \\
Pah Canyon Tuff & Tet \\
Topopah Spring Tuff & Thy \\
Calico Hills Formation & Pcp \\
Crater Flat Group & Tob \\
Prow Pass Tuff & Tet \\
Bullfrog Tuff & Til \\
Tram Tuff & Tyr \\
Lavas and Flow Breccias & Tr \\
Lithic Ridge Tuff & \\
Older Tuff & Pr \\
\hline & Paleozoic \\
\hline Paleozoic rocks, undifferentiated & \\
\hline
\end{tabular}

${ }^{1}$ Includes bedded tuff at base of most units

14 
TABLE 2.-Physical properties of rock units used in the models.

Values were derived from borehole samples, borehole logs, and surface samples ${ }^{1}$

\begin{tabular}{lrrlc}
\hline Unit & $\begin{array}{c}\text { Declination } \\
\text { deg }\end{array}$ & $\begin{array}{c}\text { Inclination } \\
\text { deg }\end{array}$ & $\begin{array}{c}\text { Magnetization } \\
\text { A/m }\end{array}$ & $\begin{array}{c}\text { Density } \\
\text { g/cm }^{3}\end{array}$ \\
\hline Qac & 0 & 0 & 0.0 & $1.5-1.8$ \\
Tfc & 170 & -30 & 1.9 & $1.8-2.0$ \\
Tma & 0 & 59 & 0.58 & 2.0 \\
Tmr & 168 & -55 & $0.8-2.7$ & $1.5-2.0$ \\
Tmx & 0 & 0 & 0.0 & 2.0 \\
Tpc & 169 & -23 & 0.94 & 2.0 \\
Tpy & 170 & 1 & 0.24 & 1.6 \\
Tpp & 154 & -62 & 1.6 & $1.4-1.9$ \\
Tpt & 322 & 52 & 1.3 & $2.2-2.4$ \\
Tht & 6 & 56 & 0.11 & $1.9-2.0$ \\
Tcp & -4 & 50 & 0.26 & $2.0-2.3$ \\
Tcb & 12 & 41 & 1.7 & $2.2-2.4$ \\
Tct & 131 & -30 & 1.2 & $2.0-2.4$ \\
Tll & 5 & 50 & 1.0 & 2.5 \\
Tlr & 251 & 62 & 0.22 & $2.0-2.4$ \\
Tt & 50 & 60 & 0.3 & 2.4 \\
Pz & 0 & 0 & 0.0 & 2.7 \\
\hline
\end{tabular}

1 Data modified from Rosenbaum and Snyder (1985), Bath and Jahren (1984), and M.R. Hudson (USGS, written commun., 1994)

2 Total declination, inclination, and magnetization

${ }^{3}$ Remanent declination, inclination, and magnetization

TABLE 3.-Physical properties of rock units used in the theoretical fault model.

Values were derived from core samples in drill-hole G-1.1

\begin{tabular}{lccc}
\hline Unit & $\begin{array}{c}\text { Declination } \\
\text { deg }\end{array}$ & $\begin{array}{c}\text { Inclination } \\
\text { deg }\end{array}$ & $\begin{array}{c}\text { Magnetization } \\
\text { A } / \mathrm{m}\end{array}$ \\
\hline Tpc & 167 & -38 & 1.1 \\
Tpt & 326 & 62 & 1.3 \\
Tcb & 13 & 49 & 1.0 \\
Tct & 141 & -42 & 1.2 \\
\hline
\end{tabular}

1 Data from Bath and Jahren (1984)

2 Total declination, inclination, and magnetization 


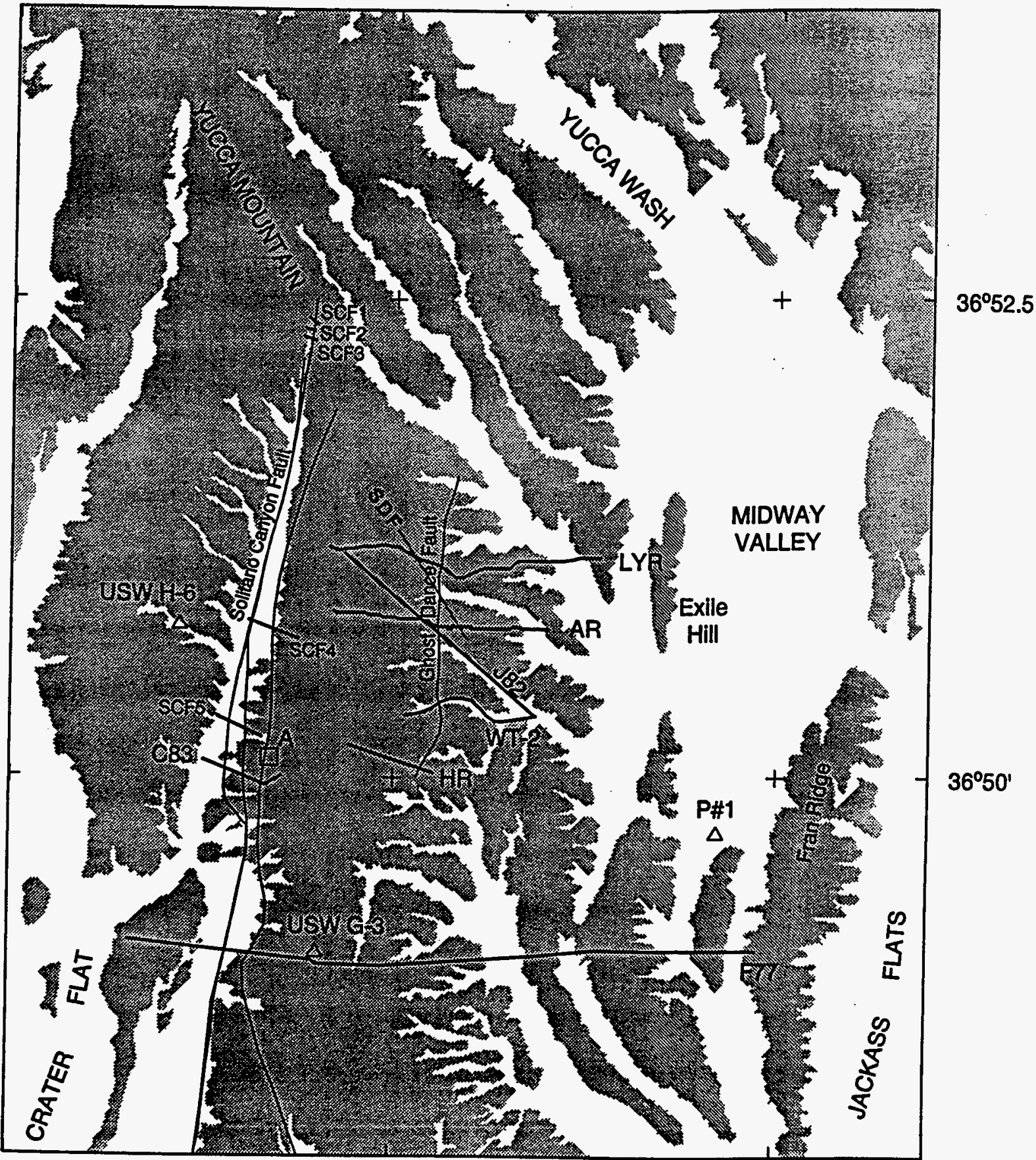

0 $5 \mathrm{KM}$

FIGURe 1.-Index map of the study area showing locations of gravity and magnetic profiles across the Ghost Dance and Solitario Canyon faults. White area, Quaternary alluvium and colluvium; Shaded area, Tertiary volcanic rocks; Box, location of aeromagnetic high described by Bath and Jahren (1985); Triangle, drill hole; SDF, Sundance fault. Geology modified from Friszell and Shulters (1990). 

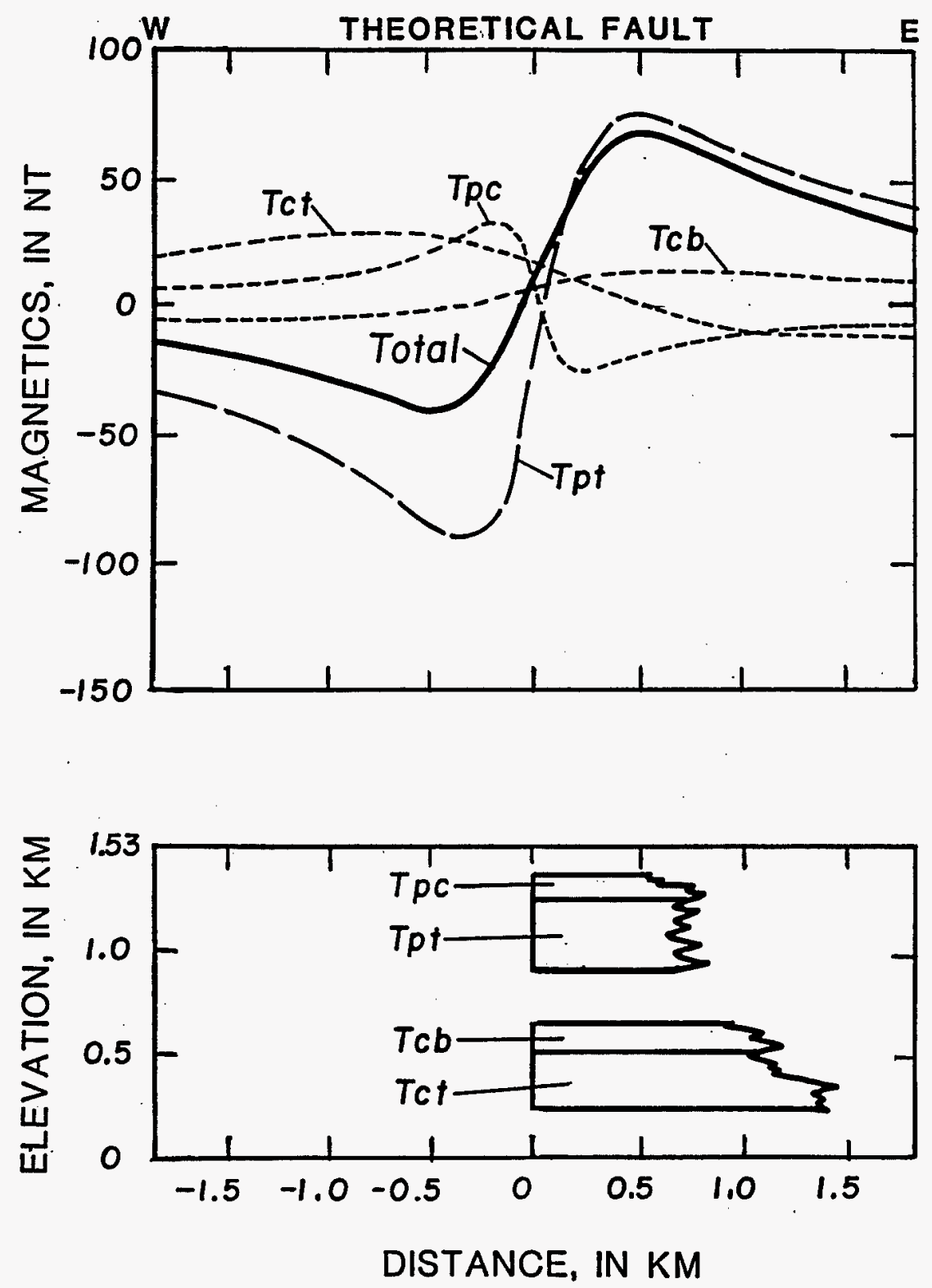

FIGURE 2.-Theoretical magnetic fault model modified from Bath and Jahren (1984). Geologic units and their properties are described in tables 1 and 3 , respectively. 


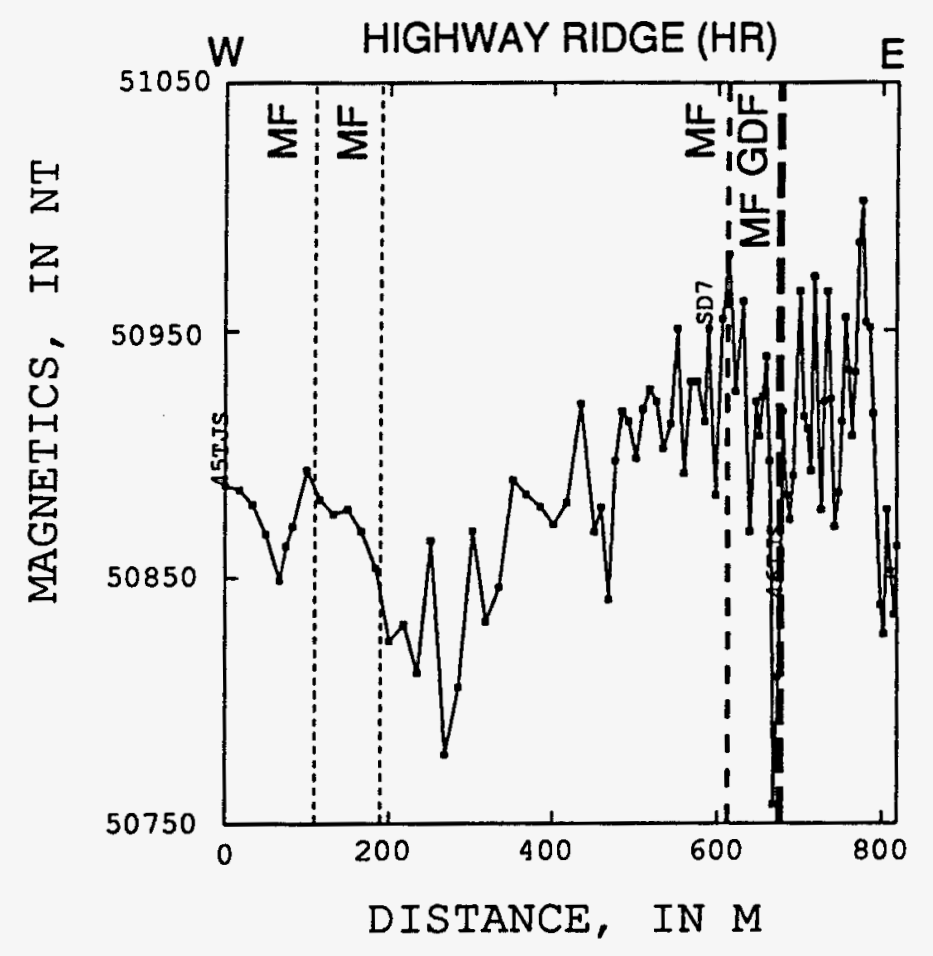

Figure 3a.-Magnetic profile of Highway Ridge. F, possible fault, fracture, or change in physical properties inferred from geophysical data; GDF, Ghost Dance fault; MF, mapped fault or fracture across or near traverse from Scott and Bonk (1984). Different dashed-line widths are used to denote confidence levels of possible faulting: Bold, high confidence; Medium, medium confidence; and Fine, low confidence. 

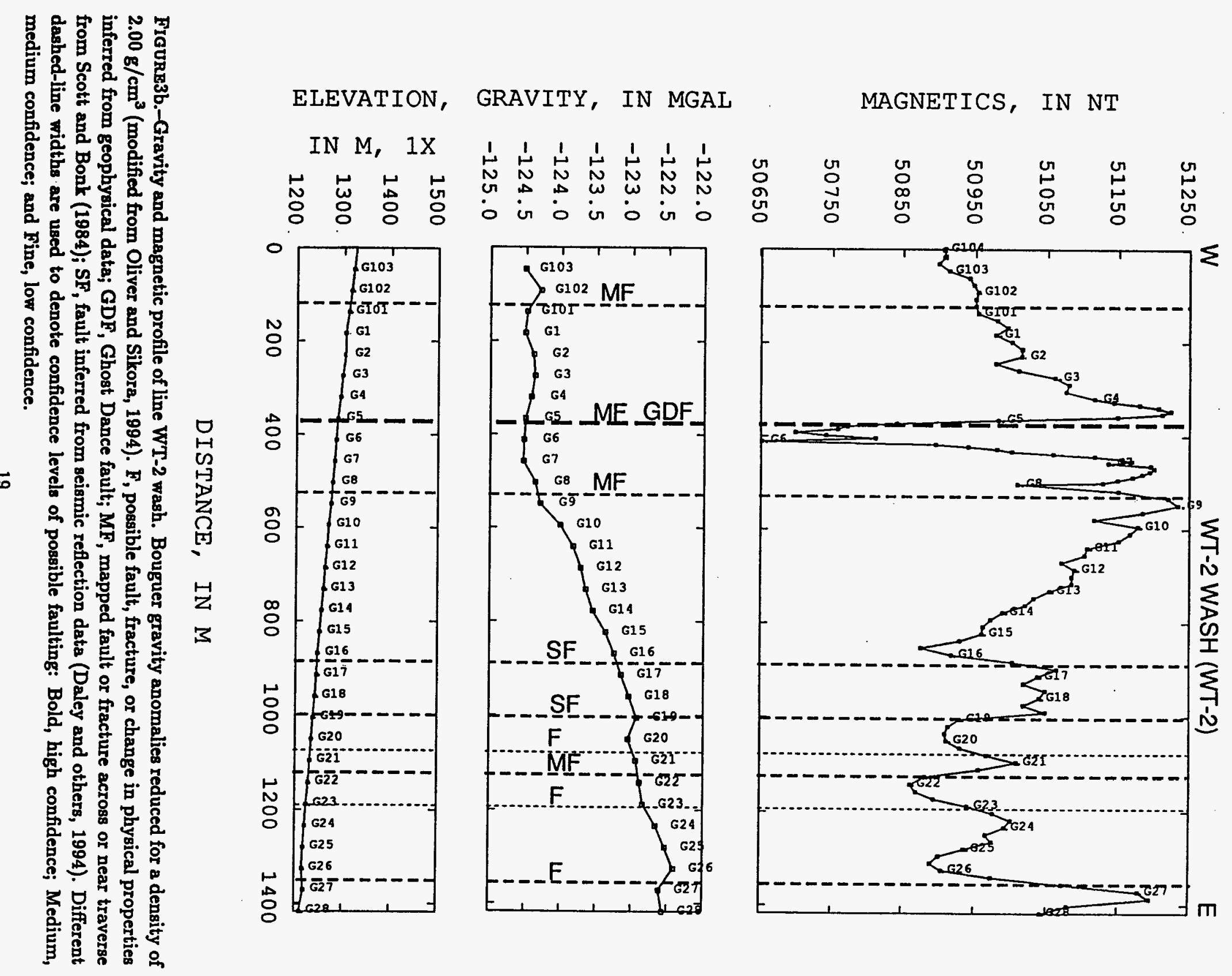


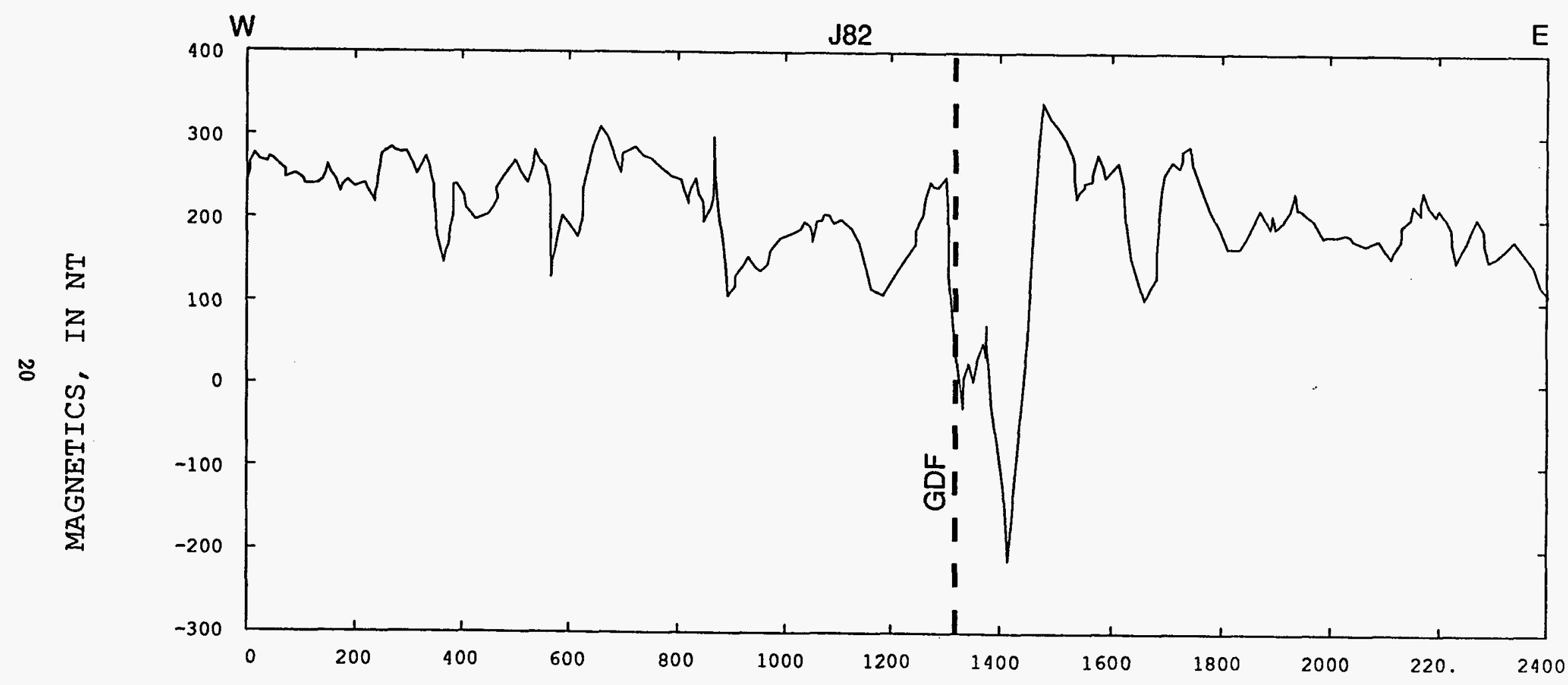

\section{DISTANCE, IN M}

FIGURE 3c.-Magnetic profile of traverse J82. Modified from Bath and Jahren (1984). GDF, inferred location of the Ghost Dance fault based on its magnetic signature. Different dashed-line widths are used to denote confidence levels of possible faulting: Bold, high confidence; Medium, medium confidence; and Fine, low confidence. 


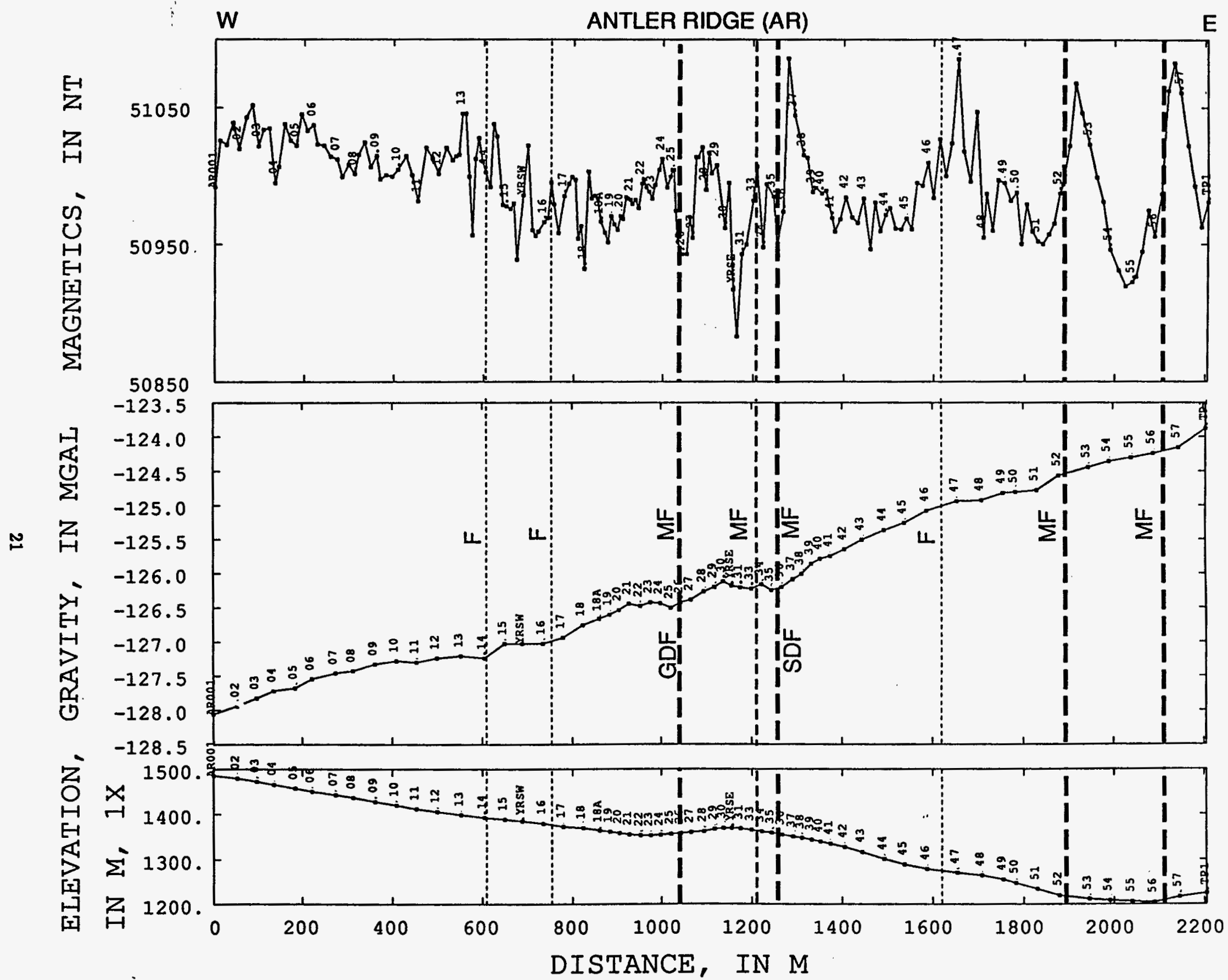

FIGURE 3d.-Gravity and magnetic profile of Antler Ridge. Bouguer gravity anomalies reduced for a density of $2.00 \mathrm{~g} / \mathrm{cm}^{3}$. F, possible fault, fracture, or change in physical properties inferred from geophysical data; GDF, Ghost Dance fault; MF, mapped fault or fracture across or near traverse from Scott and Bonk (1984); SDF, Sundance fault. Different dashed-line widths are used to denote confidence levels of possible faulting: Bold, high confidence; Medium, medium confidence; and Fine, low confidence. 
IN NI 'SDIUINSET
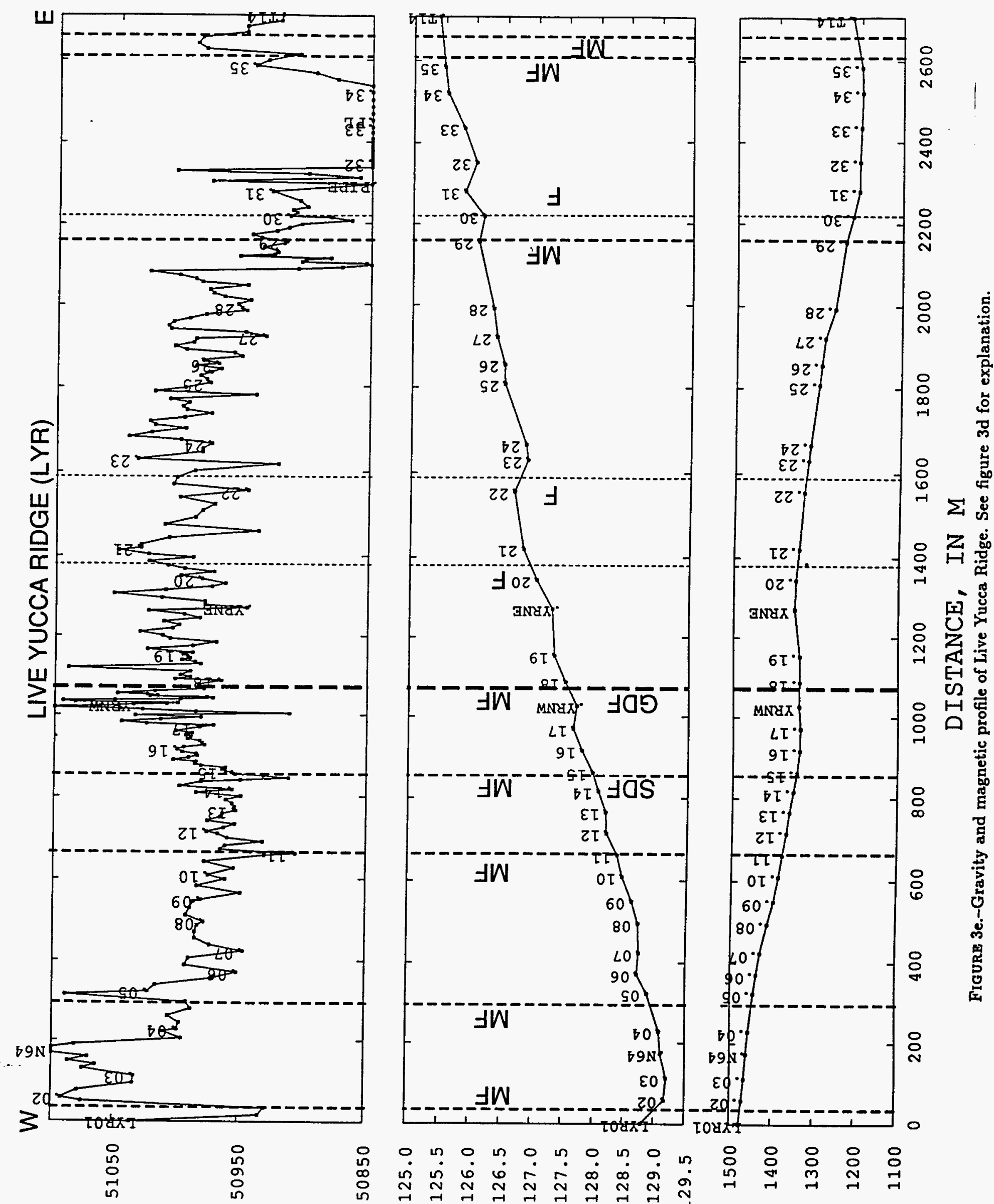

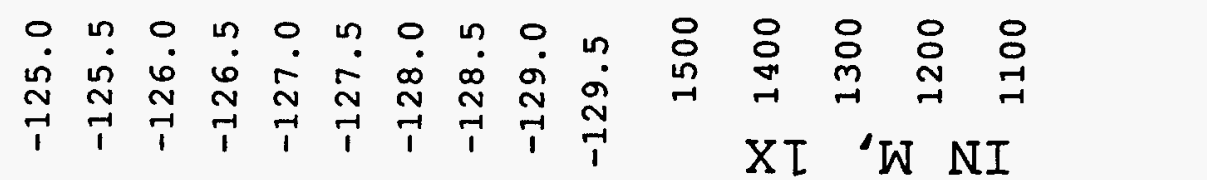

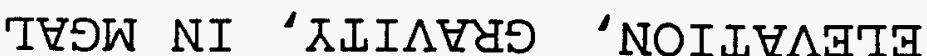




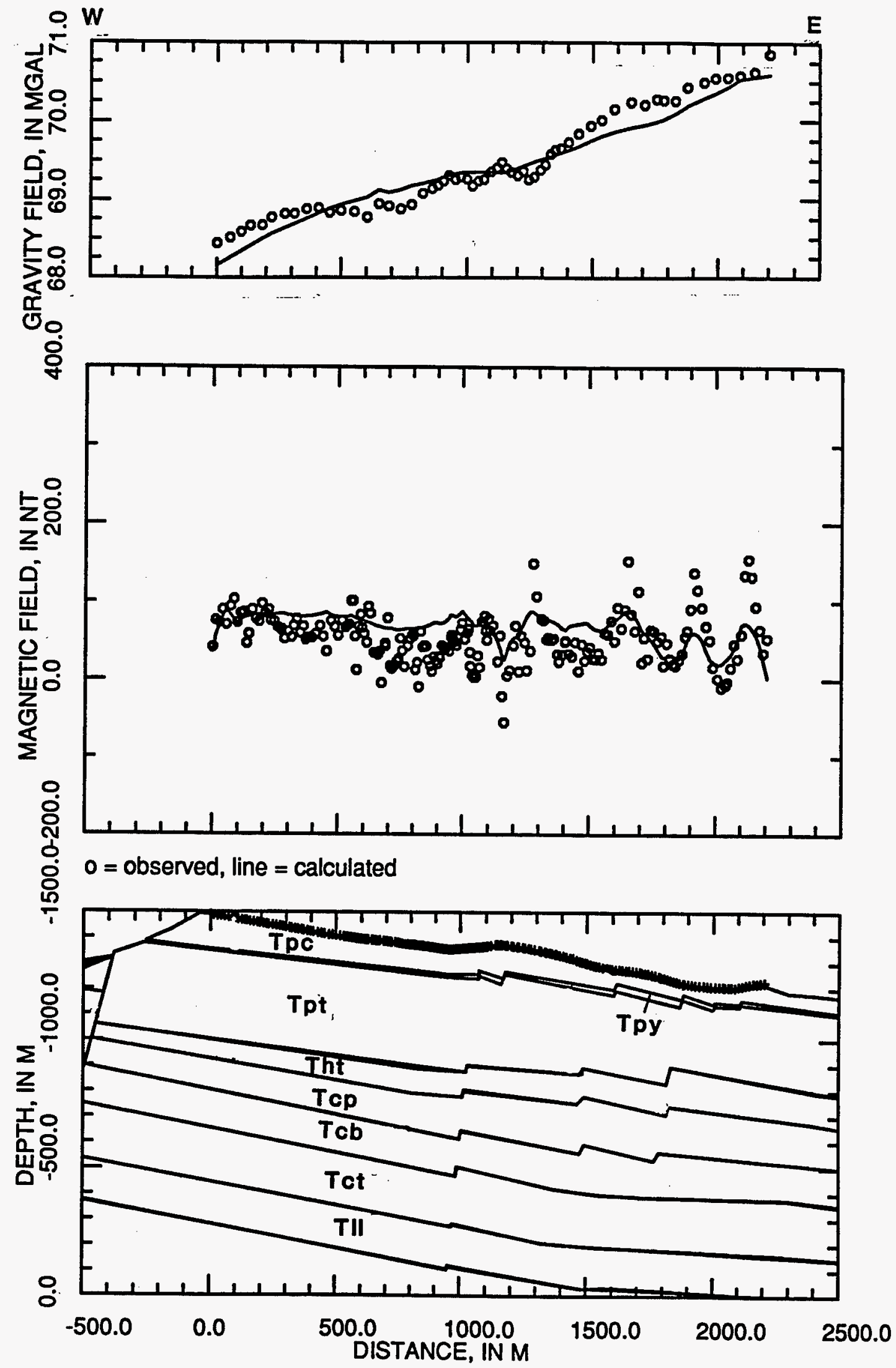

FIGURE 4.-Gravity and magnetic model along Antler Ridge. Bouguer gravity anomalies reduced for a density of $2.00 \mathrm{~g} / \mathrm{cm}^{3}$. See table 1 for description of units. Because of the overriding magnetic effect of the Topopah Spring Tuff ( $\mathrm{Tpt}$ ), inferred faults or structure below $\mathrm{Tpt}$ may not be very well constrained in the magnetic model. 


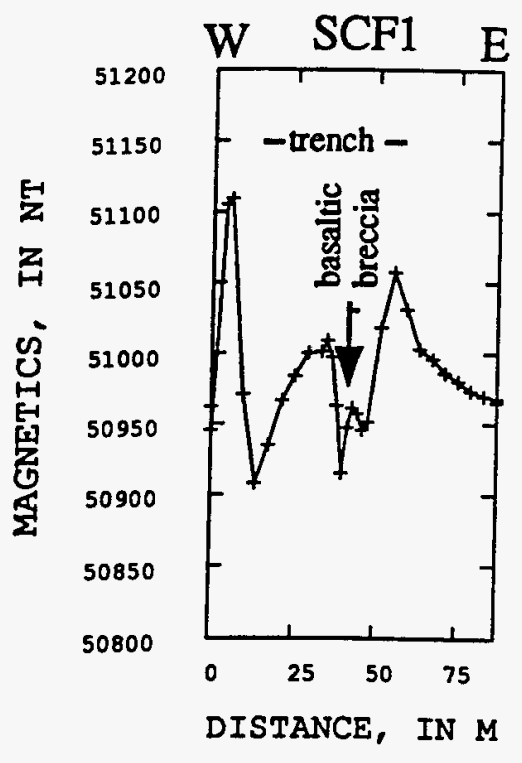

(a)

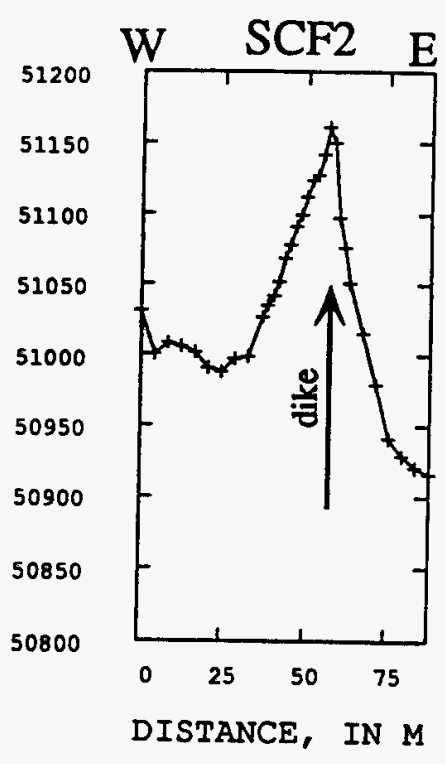

(b)

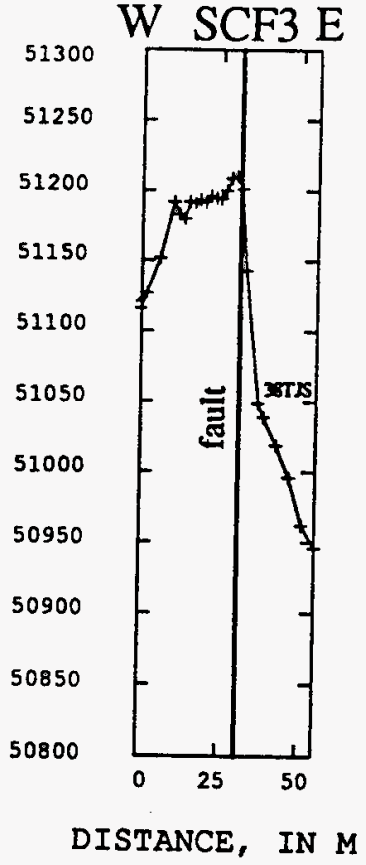

(c)

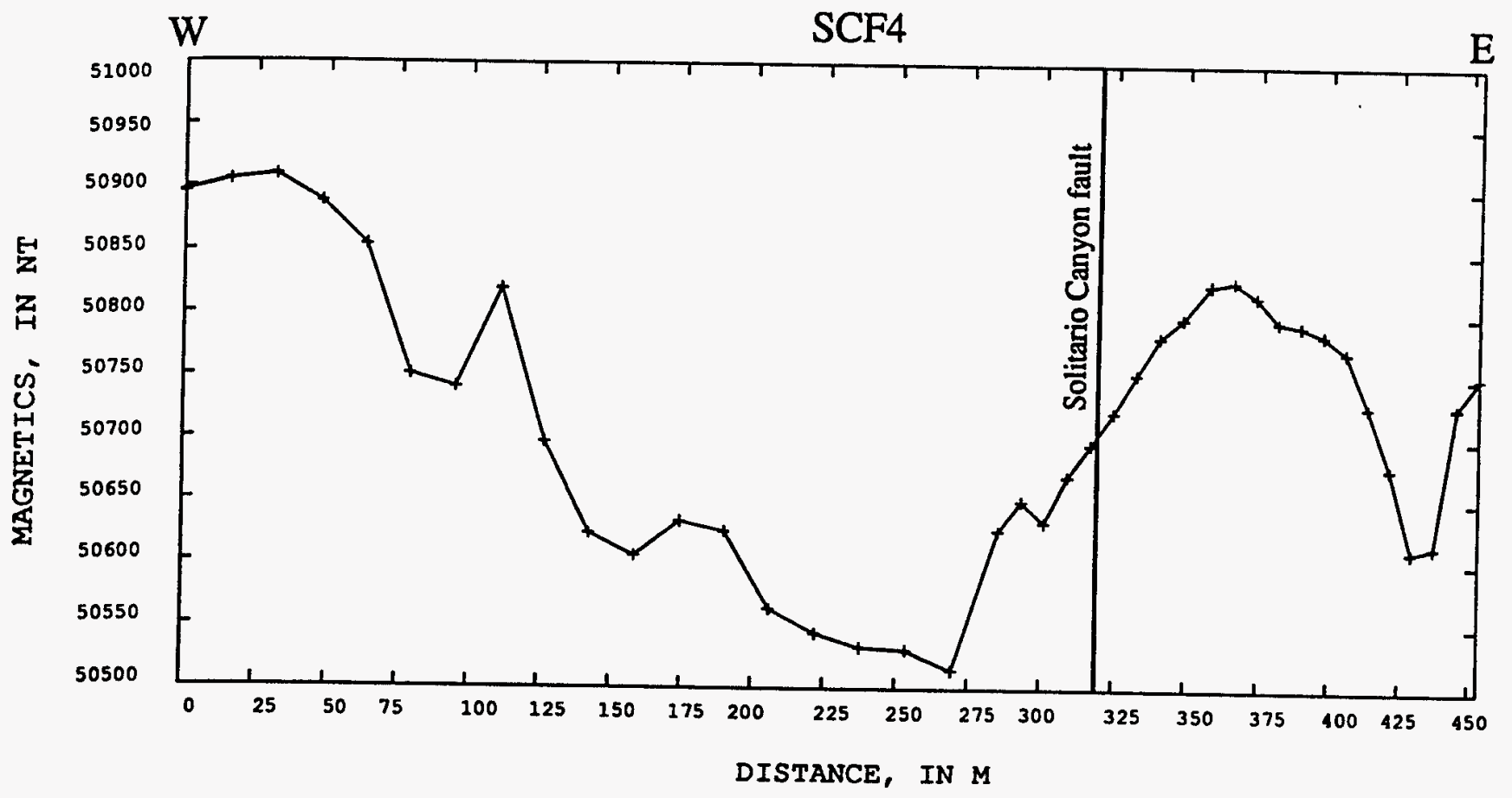

(d)

Figure 5.-Magnetic profiles across Solitario Canyon fault. 


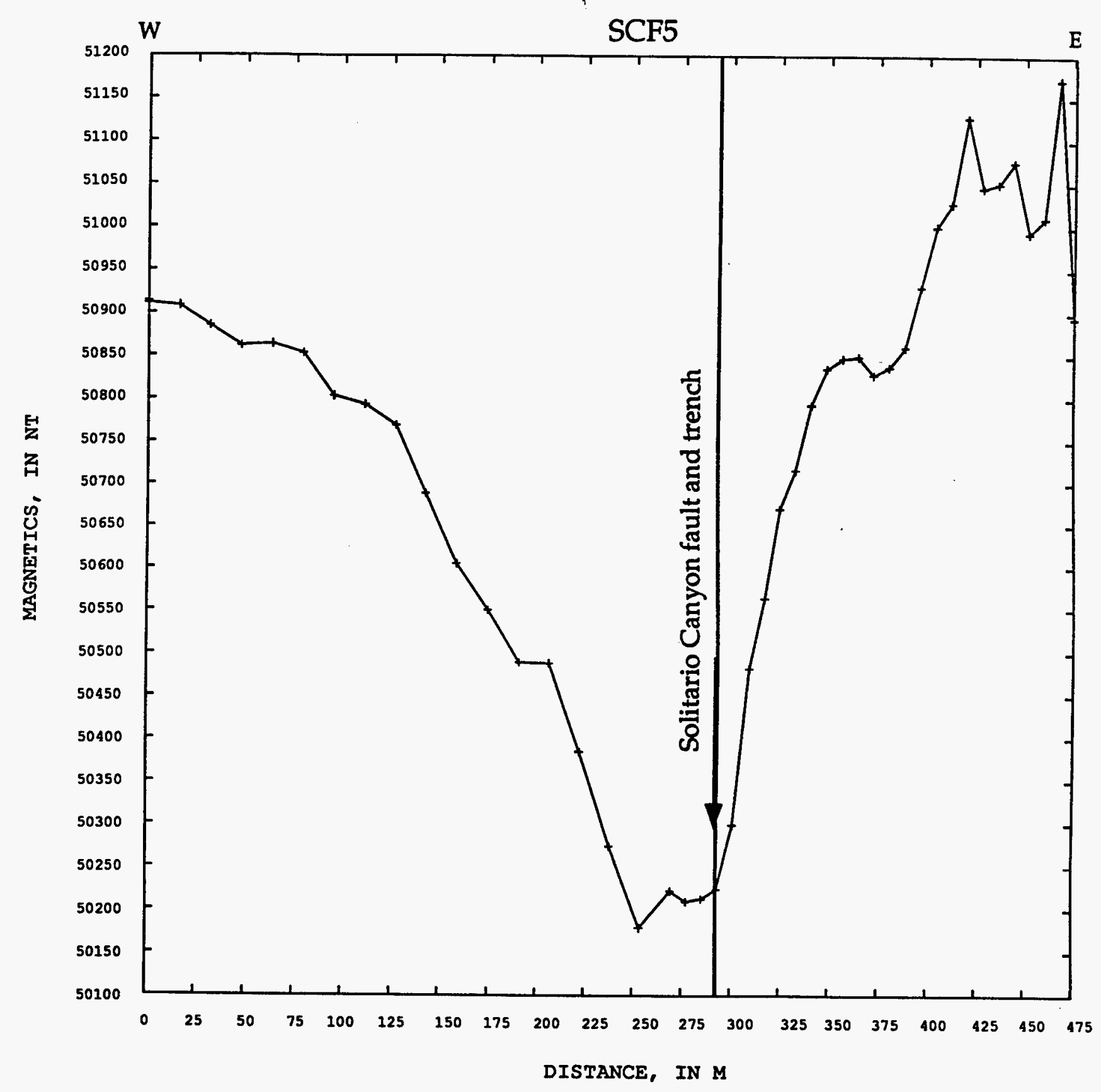

(e)

FIGURE 5.-Magnetic profiles across Solitario Canyon fault 


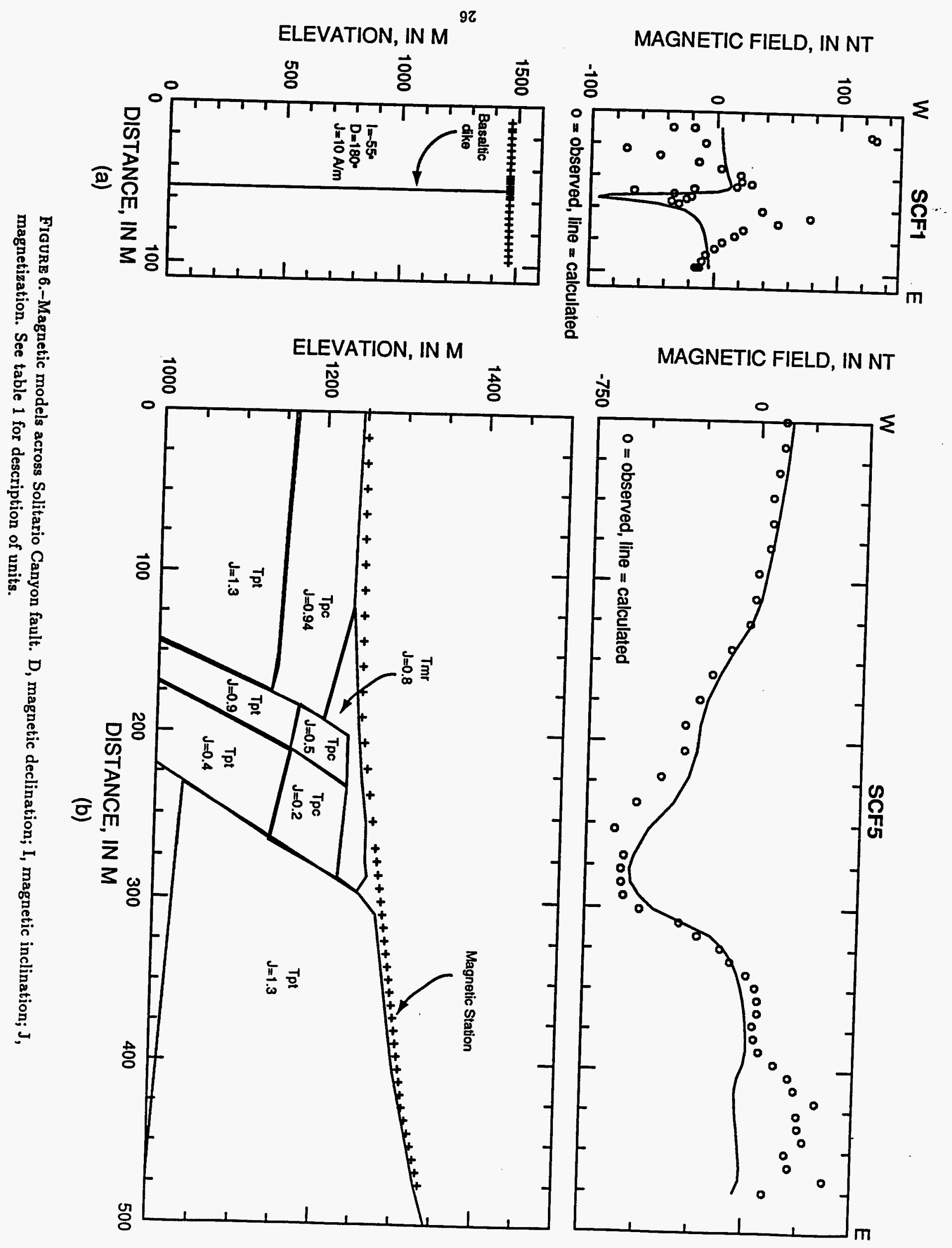




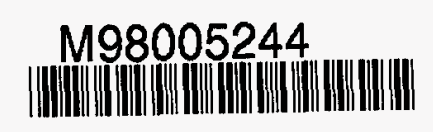

Report Number (14)U S GS-OFR-- 95-521

Publ. Date (11) $\frac{1995}{\text { USCS, XF }}$
Sponsor Code (18)
UC Category (19) 